\title{
Three invasive species occurring in the diets of fishes in a Neotropical floodplain
}

\author{
Isaac, A. ${ }^{a *}$, Fernandes, A. $^{a}$, Ganassin, MJM. ${ }^{a}$ and Hahn, NS. ${ }^{a}$ \\ aNúcleo de Pesquisa em Limnologia, Ictiologia e Aquicultura - Nupelia, Programa de Pós-Graduação em Ecologia de \\ Ambientes Aquáticos Continentais - PEA, Departamento de Biologia - DBI, Universidade Estadual de Maringá - UEM, \\ Av. Colombo, 5790, CEP 87020-900, Maringá, PR, Brazil \\ *e-mail: andrisaac@yahoo.com.br
}

Received: August 27, 2012 - Accepted: July 31, 2013 - Distributed: November. 30, 2014

\begin{abstract}
The composition of the diets of 66 species of fishes was investigated from September 2009 to June 2010 in three subsystems of the Upper Paraná River floodplain (Brazil), following invasion by the two mollusk species Limnoperna fortunei (Dunker, 1857) and Corbicula fluminea (Müller, 1774), and the macrophyte Hydrilla verticillata (L.f.) Royle. Limnoperna fortunei was consumed in all three subsystems and occurred in the diet of 15 fish species, with a high proportion in the diet of Leporinus obtusidens. Corbicula fluminea was present in the diet of Pterodoras granulosus caught in the Paraná and Ivinheima subsystems. Hydrilla verticillata occurred in the diet of Schizodon nasutus caught in the Ivinheima and Paraná subsystems. It is not yet possible to evaluate the potential of these species to control invasive mollusks in the study area or the impact of these species on the structure of the food chain. Omnivorous and herbivorous fishes in the study area may have little impact on the population of $H$. verticillata.
\end{abstract}

Keywords: introduced species, Corbicula fluminea, Limnoperna fortunei, Hydrilla verticillata, fish.

\section{Ocorrência de três espécies invasoras nas dietas de peixes em uma planície de inundação Neotropical}

\begin{abstract}
Resumo
A composição da dieta de 66 espécies de peixes foi investigada de setembro de 2009 a junho de 2010, em três subsistemas da planície de inundação do alto rio Paraná (Brasil), após a invasão das espécies de molusco Limnoperna fortunei (Dunker, 1857) e Corbicula fluminea (Müller, 1774), e da macrófita Hydrilla verticillata (L.f.) Royle. Limnoperna fortunei foi consumida em todos os subsistemas amostrados e ocorreu na dieta de 15 espécies de peixes, com grande participação na dieta de Leporinus obtusidens. Corbicula fluminea esteve presente na dieta de Pterodoras granulosus coletados nos subsistemas Paraná e Ivinheima. Hydrilla verticillata ocorreu na dieta de Schizodon nasutus, capturados nos subsistemas Ivinheima e Paraná. Até o momento não é possível avaliar o potencial destas espécies para controlar moluscos invasores na área de estudo ou o impacto destas espécies sobre a estrutura das cadeias alimentares. Peixes omnívoros e herbívoros da área de estudo podem ter pouco impacto sobre a população de $H$. verticillata.
\end{abstract}

Palavras-chave: espécies introduzidas, Corbicula fluminea, Limnoperna fortunei, Hydrilla verticillata, peixe.

\section{Introduction}

Invasive species have the potential to alter the structure of aquatic ecosystems, because of their rapid establishment and high densities (Darrigran and Damborenea, 2011; Gazulha et al., 2012). Although species distribution changes naturally over time, human activities greatly increase the rate and the spatial scale of these changes, by accidentally or deliberately moving organisms across the world (Ricciardi and MacIsaac, 2000).

According to Darrigran (1997), invasive species have as characteristics a rapid attainment of sexual maturity, great reproductive capacity, and a considerable adaptive ability in the environments (natural, artificial, fresh water, or brackish water) that they colonize.

In the Upper Paraná River, three introduced species have caused changes in the community, and their participation in the food chain of the fish assemblage has begun to receive attention (Cantanhêde et al., 2008). Limnoperna fortunei (Dunker, 1857) (Mytilidae), a freshwater bivalve native to China and Southeast Asia, was introduced into South America through the Río de la Plata watershed (Argentina) at the beginning of 1991 (Pastorino et al., 1993). In August 2001, L. fortunei was first found in the Itaipu Reservoir in Brazil, and was recorded in the floodplain of the Paraná 
River in December 2002 (Takeda et al., 2007). This species has a high invasive potential due to its reproductive and opportunist characteristics, rapidly reaches sexual maturity, and has high reproductive rates (Darrigran, 2002). The absence of competition in the freshwater environment and the association of this species with human activities greatly increases its dispersal capacity (Darrigran and Drago, 2000).

The clam Corbicula fluminea (Müller, 1774) is a bivalve native to Southeast Asia, and was first documented for South America at the end of the 1960s and beginning of the 1970s (Ituarte, 1981). This species has been documented in the Upper Paraná River floodplain since the 1990s, possibly introduced through the main channel of the Paraná River and spreading laterally to other river systems such as the Baía and Ivinheima rivers, through secondary channels that connect the main rivers (Takeda et al., 2007). It is considered an invasive species due to its high adaptability and rapid proliferation in different environments. The intensive proliferation of this clam has caused a sharp decrease in the density of native species of clams (Takeda et al., 2004).

Several species of macrophytes are easily able to disperse and regenerate, which makes them excellent invaders (Cunha et al., 2011). Hydrilla verticillata (L.f.) Royle is a rooted-submersed macrophyte (family Hydrocharitaceae) native to Australia, the Pacific Islands, Asia, and probably Africa (Madeira et al., 2007). This macrophyte was first recorded in the Upper Paraná River floodplain in 2005, where it spread quickly. Seven years after this invasion, native macrophytes still predominate in floodplain lakes, while $H$. verticillata primarily colonizes the lotic habitats of the Paraná River, such as the main and lateral channels of the river, where colonization by native macrophytes is sparse (Sousa et al., 2009, 2010). This species is similar in its morphological and ecological aspects to Egeria najas and Egeria densa (South American Hydrocharitaceae), but this non-native species is a superior competitor and can be expected to exert significant pressure in habitats colonized by these natives (Sousa, 2011). Since then it has rapidly spread along the Paraná River, infesting large areas, with high biomass production, and causing problems for navigation, fishing, and recreation activities (Sousa et al., 2009).

Due to their high biomass and density, exotic species can cause alterations in the food chain, serving as food for native fishes (Darrigran and Damborenea, 2005). Previous studies have found specimens of L. fortunei and C. fluminea in the diets of some fish species (e.g. Darrigran and Colautti, 1994; Penchaszadeh et al., 2000; Gaspar da Luz et al., 2002; Pasian Lonardoni et al., 2006; Cantanhêde et al., .2008; Oliveira et al., 2010), although there are no records of $H$. verticillata.

It is not easy to determine what happens when a species is introduced into a community, especially with respect to prey species as in this case, since little is known about the effects of exotic prey species on native communities. In some cases, non-native species can provide an important resource for native species (Schlaepfer et al., 2011), which makes it essential to investigate these relationships, to support ecosystem management plans. In this study we documented the fish species of the Upper Paraná River floodplain that include the three invasive species, described above, in their diet. We also assessed the current importance of invasive species as a food resource for the fish of this region, as well as to support future studies of the local trophic ecology, in regard to its changes after colonization by exotic species.

\section{Material and Methods}

The drainage network of the study area consists of the main channel, secondary channels, and tributaries of the Paraná River (Souza-Filho and Stevaux, 1997). The Ivinheima River is the most important tributary on the right bank of the Paraná River (Souza-Filho and Stevaux, 1997). According to these authors, all tributaries of the right bank of the Paraná River flow into a set of secondary channels formed by the Baía River, the Curutuba Channel and the lower course of the Ivinheima River. In this way the Baía and Ivinheima rivers are connected with each other and with the Paraná River.

The samples were taken in the Upper Paraná River floodplain, between September 2009 and June 2010, at sampling points located in lake and river environments distributed among the Baía (22 $43^{\prime} \mathrm{S}$ and $\left.53^{\circ} 18^{\prime} \mathrm{W}\right)$, Ivinheima $\left(22^{\circ} 49^{\prime} \mathrm{S}\right.$ and $\left.53^{\circ} 33^{\prime} \mathrm{W}\right)$ and Paraná rivers ( $22^{\circ} 49^{\prime} \mathrm{S}$ and $\left.53^{\circ} 33^{\prime} \mathrm{W}\right)$, here referred to as subsystems. In the Baía subsystem, the gillnets were set in the main channel of the river, in Guaraná Lake (connected to the river), and in Fechada Lake (isolated from the river). In the Ivinheima subsystem the gillnets were set in the main channel of the river, in Ventura Lake (isolated from the river) and in Patos Lake (connected to the river). In the Paraná subsystem, the samples were taken in the main channel of the Paraná River and in two open lakes, Garças and Pau-Véio.

Fishes were caught with gillnets of graded mesh sizes $(20,30,40,50,60,70,80,100,120,140$, and $160 \mathrm{~mm}$ between nonadjacent knots) and longlines with 40 hooks. A total of $368 \mathrm{~m}^{2}$ of nets was set at each site during $24 \mathrm{~h}$ and checked at 08:00, 16:00, and 22:00 h. Longlines were baited in the evening and checked the next morning. Fish were measured and weighed, and stomachs were removed and fixed in $4 \%$ formaldehyde for content analysis. In this study, detritivorous species were not included.

Food items were identified under a stereomicroscope. The volumetric method was used to quantify the items (for details see Hellawell and Abel, 1971). The analyses were performed by using the methods of frequency of occurrence (FO) and volumetric frequency (FV) (Hyslop, 1980). The importance of the different categories of food items was inferred from the combination of these methods in the Feeding Index (IAi\%) (Kawakami and Vazzoler, 1980), and the values shown in the results section refer to this index. 


\section{Results}

We analyzed the stomach contents of 1702 specimens belonging to 66 species, as shown in Table 1. The overall analysis of the diet revealed the presence of a large number of food items, which were grouped into 14 categories: detritus, algae, plants (aquatic and terrestrial), microcrustaceans, decapod crustaceans, mollusks, aquatic insects, terrestrial insects, aquatic invertebrates, terrestrial invertebrates, fish, Limnoperna fortunei, Corbicula fluminea and Hydrilla verticillata.

Taking into account the items consumed in the three subsystems grouped, L. fortunei occurred in the diets of 15 of the 27 species of fish that consumed some kind of mollusks, most prominently in the diets of Leporinus obtusidens $(\mathrm{IAi}=74.18 \%)$, L. macrocephalus $(\mathrm{IAi}=21.25 \%)$, L. friderici $(\mathrm{IAi}=17.87 \%)$ and L. elongatus $(\mathrm{IAi}=11.06 \%)$.
This mussel was consumed in all environments of the three subsystems, and showed the lowest incidence and a relatively small proportion in the diet of the species caught in the Ivinheima subsystem (see Tables 2 and 3).

In stomachs of members of the genus Leporinus, the valves of $L$. fortunei were broken or open, exposing the visceral mass of the mollusk.

The clam Corbicula fluminea was present only in the diet of Pterodoras granulosus, and comprised only a small proportion ( $\mathrm{IAi}=0.75 \%$ ) of the food items consumed, taking into account all environments grouped. The fish that included this clam in their diets were caught in the main channel of the Ivinheima River $(\mathrm{IAi}=1.0 \%)$ and in a connected lagoon (Guaraná Lake) in the Baía subsystem $(\mathrm{IAi}=63.11 \%)$.

Macrophytes were present in the diets of 25 species of fishes, among the 32 species that consumed any plant

Table 1. Fish species, number of stomach contents analyzed (N), and standard length (SL) in centimeters.

\begin{tabular}{|c|c|c|c|c|c|}
\hline Species & $\mathbf{N}$ & SL & Species & $\mathbf{N}$ & SL \\
\hline Acestrorhynchus lacustris & 129 & $9.2-41.1$ & Leporinus obtusidens & 43 & $7.8-29.5$ \\
\hline Ageneiosus inermis & 6 & $18.7-29.5$ & Lepthoplosternum pectorale & 7 & $5.8-7.1$ \\
\hline Astronotus crassipinnis & 1 & 21.5 & Metynnis lippincottianus & 14 & $6.7-13.2$ \\
\hline Astyanax altiparanae & 28 & $5.6-10.7$ & Moenkhausia aff. intermedia & 30 & $5.7-6.9$ \\
\hline Auchenipterus osteomystax & 49 & $8.9-71.1$ & Oxydoras eigenmanni & 2 & $6.4-10.6$ \\
\hline Brycon orbignyanus & 49 & $12.8-26.9$ & Parauchenipterus galeatus & 152 & $5.8-17.1$ \\
\hline Callichthys callichthys & 6 & $7.9-12.4$ & Piaractus mesopotamicus & 20 & $16.2-30.8$ \\
\hline Cichla kelberi & 56 & $15.1-28.5$ & Pimelodella avanhandavae & 4 & $9.1-17$ \\
\hline Cichla piquiti & 5 & $15.2-18$ & Pimelodella gracilis & 1 & 12.0 \\
\hline Clarias gariepinus & 1 & 65.0 & Pimelodus cf. argenteus & 1 & 10.7 \\
\hline Crenicichla britskii & 11 & $7.3-13.9$ & Pimelodus maculatus & 70 & $7.8-26$ \\
\hline Crenicichla haroldoi & 1 & 12.9 & Pinirampus pirinampu & 3 & $46.8-52.2$ \\
\hline Crenicichla niederleinii & 1 & 9.9 & Plagioscion squamosissimus & 13 & $17.3-38.6$ \\
\hline Eigenmannia trilineata & 3 & $12.3-16.2 *$ & Potamotrygon cf. falkneri & 6 & $25.7-43.5$ \\
\hline Eigenmannia virescens & 5 & $16-20.5^{*}$ & Pseudoplatystoma corruscans & 23 & $21.5-58.2$ \\
\hline Geophagus cf. proximus & 35 & $6.3-18.9$ & Pseudoplatystoma fasciatum & 3 & $19.5-34.4$ \\
\hline Gymnotus inaequilabiatus & 8 & $19.2-60.0 *$ & Pterodoras granulosus & 47 & $7.8-33.5$ \\
\hline Gymnotus sylvius & 9 & $19.0-65.0 *$ & Rhamdia quelen & 1 & 15.3 \\
\hline Hemiodus orthonops & 53 & $9.3-23.0$ & Rhamphichthys hahni & 4 & $30.0-64.7 *$ \\
\hline Hemisorubim platyrhynchos & 4 & $21.0-33.0$ & Rhaphiodon vulpinus & 5 & $34.2-45.7$ \\
\hline Hoplerythrinus unitaeniatus & 16 & $9.4-23.8$ & Rhinodoras dorbignyi & 1 & 13.0 \\
\hline Hoplias aff. malabaricus & 1 & 31.6 & Roeboides descalvadensis & 22 & $5.6-8.0$ \\
\hline Hoplias sp. 1 & 32 & $11.4-36.0$ & Salminus brasiliensis & 8 & $17.6-46.8$ \\
\hline Hoplias sp. 2 & 34 & $12.6-27.5$ & Salminus hilarii & 1 & 22.0 \\
\hline Hoplias sp. 3 & 11 & $17.5-32.0$ & Satanoperca pappaterra & 38 & $9.6-18.5$ \\
\hline Hoplias spp. & 3 & $23.0-27.4$ & Schizodon altoparanae & 1 & 27.8 \\
\hline Hoplosternum littorale & 89 & $5.3-20.3$ & Schizodon borellii & 111 & $8.5-28.2$ \\
\hline Hypophthalmus edentatus & 1 & 37.0 & Schizodon nasutus & 5 & $19.9-28.7$ \\
\hline Iheringichthys labrosus & 4 & $10.4-20.0$ & Serrasalmus maculatus & 58 & $4.6-21.0$ \\
\hline Leporinus elongatus & 7 & $13.0-20.0$ & Serrasalmus marginatus & 173 & $5.0-23.5$ \\
\hline Leporinus friderici & 55 & $7.4-47.2$ & Sorubim lima & 3 & $32.5-35.0$ \\
\hline Leporinus lacustris & 63 & 7.3-19.9 & Steindachnerina brevipinna & 9 & $6.8-10.4$ \\
\hline Leporinus macrocephalus & 6 & $16.0-40.0$ & Trachydoras paraguayensis & 41 & $4.5-10.7$ \\
\hline
\end{tabular}

*Total Length. 
Table 2. Fish species that included Limnoperna fortunei and Hydrilla verticillata in their diets; subsystems where they were collected and the types of environments. $\mathrm{R}=$ River; $\mathrm{CL}=$ Connected lake, $\mathrm{IL}=$ Isolated lake.

\begin{tabular}{|c|c|c|c|c|c|c|}
\hline \multirow{2}{*}{ Species } & \multicolumn{3}{|c|}{ Limnoperna fortunei } & \multicolumn{3}{|c|}{ Hydrilla verticillata } \\
\hline & Baía & Ivinheima & Paraná & Baía & Ivinheima & Paraná \\
\hline Geophagus cf. proximus & $\mathrm{R} / \mathrm{IL}$ & & $\mathrm{CL}$ & & & \\
\hline Hoplias aff. malabaricus & $\mathrm{R}$ & & & & & \\
\hline Hoplosternum littorale & & $\mathrm{CL}$ & & & & \\
\hline Leporinus elongatus & $\mathrm{R}$ & & CL & & & \\
\hline Leporinus friderici & $\mathrm{R} / \mathrm{IL}$ & $\mathrm{R}$ & $\mathrm{R} / \mathrm{CL}$ & & & $\mathrm{R}$ \\
\hline Leporinus lacustris & $\mathrm{R} / \mathrm{IL} / \mathrm{CL}$ & & $\mathrm{CL}$ & & & \\
\hline Leporinus macrocephalus & $\mathrm{CL}$ & & & & & \\
\hline Leporinus obtusidens & $\mathrm{R} / \mathrm{IL} / \mathrm{CL}$ & IL & $\mathrm{CL}$ & & & \\
\hline Pimelodus maculatus & $\mathrm{R}$ & IL & $\mathrm{R} / \mathrm{CL}$ & & & $\mathrm{CL}$ \\
\hline Potamotrygon cf. falkneri & & $\mathrm{R}$ & $\mathrm{R}$ & & & \\
\hline Pterodoras granulosus & $\mathrm{R} / \mathrm{CL}$ & $\mathrm{R}$ & CL & & $\mathrm{R} / \mathrm{IL}$ & \\
\hline Schizodon borellii & $\mathrm{IL} / \mathrm{CL}$ & & $\mathrm{CL}$ & & & $\mathrm{R} / \mathrm{CL}$ \\
\hline Schizodon nasutus & & & & & & $\mathrm{R}$ \\
\hline Serrasalmus maculatus & & & CL & & & \\
\hline Serrasalmus marginatus & & $\mathrm{R}$ & & & & \\
\hline Trachydoras paraguayensis & $\mathrm{R}$ & & & & & \\
\hline
\end{tabular}

Table 3. Relative importance of Limnoperna fortunei and Hydrilla verticillata in the diet of fish species, measured by the Feeding Index (IAi\%) in the subsystems where they were collected.

\begin{tabular}{|c|c|c|c|c|c|c|}
\hline \multirow{2}{*}{ Species } & \multicolumn{3}{|c|}{ Limnoperna fortunei } & \multicolumn{3}{|c|}{ Hydrilla verticillata } \\
\hline & Baía & Ivinheima & Paraná & Baía & Ivinheima & Paraná \\
\hline Geophagus cf. proximus & 0.78 & & 0.06 & & & \\
\hline Hoplias aff. malabaricus & 1.52 & & & & & \\
\hline Hoplosternum littorale & & 0.06 & & & & \\
\hline Leporinus elongatus & 100 & & 0.62 & & & \\
\hline Leporinus friderici & 58.14 & 0.02 & 22.56 & & & 0.61 \\
\hline Leporinus lacustris & 17.87 & & 13.95 & & & \\
\hline Leporinus macrocephalus & 37.36 & & & & & \\
\hline Leporinus obtusidens & 99.45 & 0.44 & 90.77 & & & \\
\hline Pimelodus maculatus & 1.08 & 0.001 & 1.04 & & & 0.27 \\
\hline Potamotrygon cf. falkneri & & 4.37 & 0.87 & & & \\
\hline Pterodoras granulosus & 1.36 & 0.05 & 27.05 & & 0.003 & \\
\hline Schizodon borellii & 0.0004 & & 1.72 & & & 0.35 \\
\hline Schizodon nasutus & & & & & & 98.91 \\
\hline Serrasalmus maculatus & & & 0.11 & & & \\
\hline Serrasalmus marginatus & & 0.001 & & & & \\
\hline Trachydoras paraguayensis & 0.03 & & & & & \\
\hline
\end{tabular}

item (leaves, fruits, seeds, roots), and $H$. verticillata occurred in the diet of only five species (see Table 3 ). This invasive macrophyte comprised a high proportion of the diet of Schizodon nasutus (IAi $=90.86 \%$ ), and was an accessory item in the diets of $L$. friderici (IAi $=0.13 \%$ ), Schizodon borellii (IAi $=0.07 \%)$, Pimelodus maculatus (IAi $=0.02 \%$ ) and $P$. granulosus $(\mathrm{IAi}=0.001 \%)$, including the food items consumed in all environments together. The consumption of $H$. verticillata was observed in two environments of the Ivinheima subsystem and in three of the Paraná subsystem, but was not recorded in stomachs of fish caught in the Baía subsystem (see Table 2). The proportion of this macrophyte in the diets of fishes in each of the three subsystems is shown in Table 3.

\section{Discussion}

Exotic species may transform food chains (Darrigran and Damborenea, 2005). If on the one hand the fish have the potential to control the populations of exotic species, as suggested by Oliveira et al. (2010), which may minimize their impact on other species, on the other the fish can promote the dispersal of invasives that are able to pass intact through the digestive tract of their predators, as 
suggested by Cantanhêde et al. (2008) in studies conducted in the Upper Paraná River.

In this study we recorded the consumption of $L$. fortunei for 15 fish species, and of $C$. fluminea by only one species. In a study conducted by Oliveira et al. (2010), also in the Upper Paraná River basin but in a reservoir, 24 species of fishes consumed L. fortunei and 12 included C. fluminea in their diets. As noted by the authors, the consumption of these species shows great interspecific, interannual, and spatial variation. Although our study did not measure the degree of digestion of the bivalves, our observations corroborated the study conducted by Oliveira et al. (2010), who found a proportion of fragmented valves and digested muscle tissue in the stomach contents of specimens of the genus Leporinus.

Cantanhêde et al. (2008) associated the consumption of the two species of clam by $P$. granulosus with the abundance of these bivalves at the sampling sites. In their study conducted between 2004 and 2005, Cantanhêde et al. (2008) observed that $C$. fluminea composed $95 \%$ of the diet of P. granulosus in the Baía River and its floodplain lakes. Between 2009 and 2010, the same species of mollusk had very little importance in the diet of fish, and all specimens that consumed C. fluminea were captured in habitats of the Ivinheima and Paraná subsystems. Although P. granulosus consumed L. fortunei, this mollusk composed less than $1 \%$ of the diet of this fish, even grouping all studied environments together. These data suggest that it is essential to perform a combined analysis of the consumption of exotic mollusks and their abundances at the sites sampled, in order to confirm the importance of their availability for predation, because the consumption of these species may also be associated with a decrease in the abundance of other resources. This information is important to assess the extent to which predatory fish can really control invasive mollusks.

According to Hahn et al. (2004) the majority of fish species in the study area show a high trophic adaptability in response to environmental variations. This feature, together with the time that invasive mollusks occur in the area and their present high abundance, should favor their exploitation by fish species, especially the omnivorous ones.

For now, we can conclude only that L. fortunei and $C$. fluminea are being consumed by several species of fishes. Without an integrated and long-term approach, it is not possible to evaluate the potential of these species to effectively control invasive mollusks in the Upper Paraná River floodplain, or the impact of these mollusks on the structure of the food chain in this ecosystem.

The invasive macrophyte Hydrilla verticillata has a similar architecture to the native Egeria najas (Cunha et al., 2011). During the study period, $H$. verticillata was important only in the diet of $S$. nasutus.

Hydrilla verticillata did not occur in the diet of any species of fish in the Baía River and its lakes, and the lack of this macrophyte in these habitats (Sousa et al., 2009) may explain its absence in the diet. On the other hand, Sousa et al. (2009) reported that they did not find $H$. verticillata in the Ivinheima environments, and in this study the species was recorded in the diet of $P$. granulosus caught in the river channel and in an isolated lake associated with this subsystem. The specimen was caught in a low-water period and therefore must have consumed the macrophyte at the location where it was collected, rather than having consumed it in the Paraná River and then migrating to the lake. According to Sousa et al. (2009) the successful colonization of $H$. verticillata occurred in the main channel of the Paraná River. In fact, the highest occurrences of macrophytes in the diet of the species were recorded in habitats associated with this river, especially in the main river channel, where $H$. verticillata is highly abundant.

In general, the IAi\% showed a low importance of $H$. verticillata in the diet of predators, and there is no information on the palatability or nutritional quantity and quality of this species. Although they do consume macrophytes, omnivorous and herbivorous fishes in the study area may have little impact on the population of $H$. verticillata, given the high biomass of this plant (Sousa et al., 2010).

Comparing this study with others that recorded the proportions of L. fortunei and C. fluminea in the diet of fishes, we observed an inconstancy in the consumption of these species. Considering the high abundance of the three non-native species and the length of time that they have been present in the study area, their proportion in the diet of fish species is still low. However, the diversity of resources available in the three subsystems studied may explain the preference of fishes for native resources.

We suggest that the species with potential to control the populations of L. fortunei and C. fluminea be further investigated, since only long-term information can reveal patterns of consumption of non-native species by fish. For $H$. verticillata, it is possible that fish act more as facilitators of growth and dispersal than as population controllers, since they apparently merely prune the plants, consuming only parts of them.

\section{Acknowledgements}

The authors express their appreciation to Nupélia (Núcleo de Pesquisas em Limnologia, Ictiologia e Aquicultura), to the PELD project (Site 6 of the Brazilian Long-Term Ecological Research program), and to PEA (Programa de Pós-graduação em Ecologia de Ambientes Aquáticos Continentais) for their financial support and infrastructure; and to CAPES (Coordenação de Aperfeiçoamento de Pessoal de Nível Superior) for financial support. The authors also thank the research staff of the laboratories of Ecology of Aquatic Macrophytes and Zoobenthos, especially Fernando A. Ferreira for his help in the identification of exotic species, and Dr. Sidinei M. Thomaz for helpful comments on the manuscript. The English language been revised by J. W. Reid (Virginia Museum of Natural History). 


\section{References}

CANTANHÊDE, G., HAHN, NS., GUBIANI, ÉA. and FUGI, R., 2008. Invasive molluscs in the diet of Pterodoras granulosus (Valenciennes, 1821) (Pisces, Doradidae) in the Upper Paraná River floodplain, Brazil. Ecology Freshwater Fish, vol. 17, no. 1, p. 47-53. http://dx.doi.org/10.1111/j.1600-0633.2007.00258.x.

CUNHA, ER., THOMAZ, SM., EVANGELISTA, HBA., CARNIATO, J., SOUZA, CF. and FUGI, R., 2011. Small-sized fish assemblages do not differ between a native and a recently established non-indigenous macrophyte in a Neotropical ecosystem. Natureza \& Conservação, vol. 9, no. 1, p. 61-66. http://dx.doi. org/10.4322/natcon.2011.007.

DARRIGRAN, G., 1997. Invasores en la Cuenca del Plata. Ciencia Hoy. Revista de Divulgación y Tecnológica de la Asociación Ciencia Hoy, vol. 38, no. 7, p. 1-6.

DARRIGRAN, G., 2002. Potential impact of filter-feeding invaders on temperate inland freshwater environments. Biological Invasions, vol. 4, no. 1/2, p. 145-156. http://dx.doi. org/10.1023/A:1020521811416.

DARRIGRAN, G. and COLAUTTI, D., 1994. Potencial control biológico del molusco invasor Corbicula fluminea (Müller, 1774) en el Río de La Plata. Comunicaciones de la Sociedad Malacológica del Uruguay, vol. 7, p. 368-373.

DARRIGRAN, G. and DAMBORENEA, MC., 2005. El mejillón dorado Limnoperna fortunei (Dunker, 1857) en la Cuenca del Plata. In PENCHASZADEH, PE. (Coord.). Invasores: invertebrados exóticos en el Río de la Plata y región marina aledaña. Buenos Aires: Eudeba. p. 39-102.

DARRIGRAN, G. and DAMBORENEA, C., 2011. Ecosystem engineering impact of Limnoperna fortunei in South America. Zoological Science, vol. 28, no. 1, p. 1-7. http://dx.doi.org/10.2108/ zsj.28.1. PMid:21186940

DARRIGRAN, G. and DRAGO, IG., 2000. Invasion of the exotic freshwater mussel Limnoperna fortunei (Dunjer, 1857) (Bivalvia: Mytilidae) in South America. The Nautilus, vol. 114, no. 2, p. 69-73.

GASPAR DA LUZ, KD., FUGI, R., ABUJANRA, F. and AGOSTINHO, AA., 2002. Alterations in the Pterodoras granulosus (Valenciennes, 1833) (Osteichthyes, Doradidae) diet due to the abundance variation of a bivalve invader species in the Itaipu Reservoir, Brazil. Acta Scientiarum = Acta Scientiarum. Biological Sciences, vol. 24, no. 2, p. 427-432.

GAZULHA, V., MANSUR, MCD., CYBIS, LF. and AZEVEDO, SMFO., 2012. Grazing impacts of the invasive bivalve Limnoperna fortunei (Dunker, 1857) on single-celled, colonial and filamentous cyanobacteria. Revista Brasileira de Biologia $=$. Brazilian Journal of Biology, vol. 72, no. 1, p. 33-39.

HAHN, NS., FUGI, R. and ANDRIAN, IF., 2004. Trophic ecology of the fish assemblages. In THOMAZ, SM., AGOSTINHO, AA. and HAHN, NS. (Eds.). The Upper Paraná River and its floodplain: physical aspects, ecology and conservation. Leiden: Backhuys Publishers. p. 247-269.

HELLAWELL, JM. and ABEL, R., 1971. A rapid volumetric method for the analysis of the food of fishes. Journal of Fish Biology, vol. 3, no. 1, p. 29-37. http://dx.doi.org/10.1111/j.1095-8649.1971. tb05903.x.
HYSLOP, EJ., 1980. Stomach contents analysis review of methods and their applications. Journal of Fish Biology, vol. 17, no. 4, p. 411-429. http://dx.doi.org/10.1111/j.1095-8649.1980.tb02775.x.

ITUARTE, C., 1981. Primera noticia acerca de la introducción de pelecípodos asiáticos en el área rioplatense (Mollusca: Corbiculidae). Neotropica, vol. 27, p. 79-83.

KAWAKAMI, E. and VAZZOLER, G., 1980. Método gráfico e estimativa de índice alimentar aplicado no estudo de alimentação de peixes. Boletim do Instituto Oceonográfico, vol. 29, no. 2, p. 205-207. http://dx.doi.org/10.1590/S0373-55241980000200043.

MADEIRA, PT., COETZEE, JA., CENTER, TD., WHITE, EE. and TIPPING, PW., 2007. The origin of Hydrilla verticillata recently discovered at a South African dam. Aquatic Botany, vol. 87, no. 2, p. 176-180. http://dx.doi.org/10.1016/j.aquabot.2007.04.008.

OLIVEIRA, CRC., FUGI, R., BRANCALHÃO, KP. and AGOSTINHO, AA., 2010. Fish as Potential Controllers of Invasive Mollusks in a Neotropical Reservoir. Natureza \& Conservação, vol. 8, no. 2, p. 140-144. http://dx.doi.org/10.4322/natcon.00802006.

PASIAN LONARDONI, AP., GOULART, E., FONTES DE OLIVEIRA, E. and FEDATTO ABELHA, MC., 2006. Hábitos alimentares e sobreposição trófica das raias Potamotrygon falkneri e Potamotrygon motoro (Chondrichthyes, Potamotrygonidae) na planície alagável do alto rio Paraná, Brasil. Acta Scientiarum: Biological Sciences, vol. 28, no. 3, p. 195-202.

PASTORINO, G., DARRIGRAN, G., MARTÍN, S. and LUNASCHI, L., 1993. Limnoperna fortunei (Dunker, 1857) (Mytilidae), nuevo bivalvo invasor em águas del Río de La Plata. Neotropical, vol. 39 , no. $101 / 102$, p. 171-175.

PENCHASZADEH, PE., DARRIGRAN, G., ÂNGULO, C., AVERBUJ, A., BRÖGGER, M., DOGLIOTTI, A. and PÍREZ, N., 2000. Predation of the invasive freshwater mussel Limnoperna fortunei (Dunker, 1857) (Mytilidae) by the fish Leporinus obtusidens Valenciennes, 1846 (Anostomidae) in the Rio de la Plata, Argentina. Journal of Shellfish Research, vol. 19, no. 1, p. 229-231.

RICCIARDI, I. and MACISAAC, HJ., 2000. Recent mass invasion of the North American Great Lakes by Ponto-Caspian species. Trends in Ecology \& Evolution, vol. 15, no. 2, p. 62-65. http:// dx.doi.org/10.1016/S0169-5347(99)01745-0.PMid:10652557

SCHLAEPFER, MA., SAX, DF. and OLDEN, JD., 2011. The potential conservation value of non-native species. Conservation Biology: the journal of the Society for Conservation Biology, vol. 25 , no. 3 , p. 428-437. http://dx.doi.org/10.1111/j.15231739.2010.01646.x. PMid:21342267

SOUSA, WTZ., 2011. Hydrilla verticillata (Hydrocharitaceae), a recent invader threatening Brazil's freshwater environments: a review of the extent of the problem. Hydrobiologia, vol. 669, no. 1, p. 1-20. http://dx.doi.org/10.1007/s10750-011-0696-2.

SOUSA, WTZ., THOMAZ, SM. and MURPHY, KJ., 2010. Response of native Egeria najas Planch. and invasive Hydrilla verticillata (L.f.) Royle to altered hydroecological regime in a subtropical river. Aquatic Botany, vol. 92, no. 1, p. 40-48. http:// dx.doi.org/10.1016/j.aquabot.2009.10.002.

SOUSA, WTZ., THOMAZ, SM., MURPHY, KJ., SILVEIRA, MJ. and MORMUL, RP., 2009. Environmental predictors of the occurrence of exotic Hydrilla verticillata (L.f.) Royle and native Egeria najas Planch. in a sub-tropical river floodplain: the Upper River Paraná, Brazil. Hydrobiologia, vol. 632, no. 1, p. 65-78. http://dx.doi.org/10.1007/s10750-009-9828-3. 
SOUZA-FILHO, EE. and STEVAUX, JC., 1997. Geologia e geomorfologia do complexo rio Baía, Curutuba e Ivinheima. In VAZZOLER, AEAM., AGOSTINHO, AA. and HAHN, NS. (Eds). A Planície de Inundação do Alto Rio Paraná: Aspectos Físicos, Biológicos e Sócio-econômicos. Maringá: EDUEM, Nupelia. p. 3-46.

TAKEDA, AM., FUJITA, DS. and FONTES JUNIOR, HM., 2007. Bivalves invasores no rio Paraná. In Tópicos de Malacologia -
Ecos do XVIII EBRAM, 2007, Rio de Janeiro. Rio de Janeiro: Sociedade Brasileira de Malacologia. p. 81.

TAKEDA, AM., FUJITA, DS. and FONTES JUNIOR, HM., 2004. Perspectives on exotic bivalves proliferation in the Upper Paraná River floodplain. In AGOSTINHO, AA., RODRIGUES, L., GOMES, LC., THOMAZ, SM. and MIRANDA, LE. (Eds.). Structure and Functioning of the Paraná River and Its Floodplain LTER-site 6 (PELD sitio 6). Maringá: EDUEM. p. 97-100. 